\title{
Block of Ca Channels in Rat Central Neurons by the Spider Toxin $\omega$-Aga-IIIA
}

\author{
Isabelle M. Mintz \\ Department of Neurobiology, Harvard Medical School, Boston, Massachusetts 02115
}

The effects of the spider toxin $\omega$-Aga-IIIA were studied on Ca channel currents in rat central neurons. In hippocampal CA1 pyramidal neurons, $\omega$-Aga-IIIA blocked $\sim 70 \%$ of the high-threshold $\mathrm{Ca}$ currents and had no effect on low-threshold T-type current. Occlusion experiments with blockers of L-, N-, and P-type Ca currents showed that $\omega$-Aga-IIIA abolished dihydropyridine-sensitive L-type current and blocked a substantial fraction of the $\omega$-conotoxin (CgTX)-sensitive $\mathbf{N}$-type and $\omega$-Aga-IVA-sensitive P-type Ca currents. The highthreshold current remaining with saturating concentrations of nimodipine, $\mathrm{CgTX}$, and $\omega$-Aga-IVA was also partially blocked by $\omega$-Aga-IIIA in a variety of central neurons. Block of P-type current by $\omega$-Aga-IIIA was investigated in more detail in cerebellar Purkinje neurons. Block was potent ( $K_{d}$ $\sim 0.5 \mathrm{~nm}$ ), but incomplete and voltage dependent. Tail current activation curves showed that channel gating is shifted in the depolarizing direction by $\sim 7 \mathrm{mV}$. The instantaneous current-voltage curve for P-type current was also altered; the toxin reduced Ba-carried inward currents by $\sim 40 \%$ and had little effect on Cs-carried outward currents. The partial, voltage-dependent reduction of P-type $\mathrm{Ca}$ current can be accounted for by a combination of toxin effects on channel permeation and gating.

[Key words: Ca channels, CA1 pyramidal neurons, Purkinje neurons, ion channel block, spider toxin, w-Aga-IIIA]

Neurons possess multiple types of Ca channels (Tsien et al., 1988; Bean, 1989; Hess, 1990; Swandulla et al., 1991; Llinas et al., 1992; Miller, 1992), as evidenced by single-channel recordings (Nowycky et al., 1985a; Fisher et al., 1990; Mogul and Fox, 1991; O'Dell and Alger, 1991), multiple whole-cell Ca current components with distinct kinetics and voltage dependence (Carbone and Lux, 1984; Fox et al., 1987a,b), and the variety of Ca channel clones (Hui et al., 1991; Mori et al., 1991; Snutch et al., 1991; Williams et al., 1992a; Ellinor et al., 1993; Soong et al., 1993; for review, see Tsien et al., 1991; Snutch and Reiner, 1992). In addition to dihydropyridine compounds used for studies of L-type Ca channels in muscle cells and neurons (Rampe and Triggle, 1989), high-affinity toxins are useful for distinguishing neuronal Ca channels. The Conus peptide $\omega$-conotoxin

\footnotetext{
Received Apr. 13, 1993; revised Oct. 14, 1993; accepted Oct. 26, 1993.

Many thanks to Bruce Bean, Chung-Chin Kuo, Kenton Swartz, and Linda Boland for helpful discussions and suggestions and to Mike Adams for his generous gift of the toxins $\omega$-Aga-IIIA and $\omega$-Aga-IVA. This work was supported by grants from the National Institutes of Health (HL 35034 and NS02253 to B. P. Bean and NS24472 to M. E. Adams).

Correspondence should be addressed to Isabelle M. Mintz, Department of Neurobiology, Harvard Medical School, 220 Longwood Avenue, Boston, MA 02115. Copyright (C) 1994 Society for Neuroscience $0270-6474 / 94 / 142844-10 \$ 05.00 / 0$
}

GVIA (CgTX) (Olivera et al., 1985) has helped purify $\mathrm{N}$-type Ca channels from rat brain (McEnery et al., 1991; Witcher et al., 1993), identify cDNA clones of their $\alpha 1$ subunits (Williams et al., 1992a,b; Fujita et al., 1993), and evaluate their role in various cellular processes (Kerr and Yoshikami, 1984; Komuro and Rakic, 1992; Pfrieger et al., 1992) and their susceptibility to transmitter and second messenger modulations (Tsien et al., 1988; Anwyl, 1991). The spider toxin $\omega$-Aga-IVA from Agelenopsis aperta venom blocks with high affinity and high selectivity high-threshold P-type Ca channels, which were first recognized as a distinct $\mathrm{Ca}$ channel type in cerebellar Purkinje neurons (Llinas et al., 1989, 1992). It has helped demonstrate that $\mathrm{Ca}$ channels similar to the P-type are present in neurons other than Purkinje cells (Mintz et al., 1992a,b), respond to transmitter modulation (Mintz and Bean, 1993; Mogul et al., 1993), and contribute to glutamate release from rat brain synaptosomes (Turner et al., 1992).

Another peptide toxin, $\omega$-Aga-IIIA, also blocks with high affinity some Ca channels. It has potent effects on neuronal $\mathrm{N}$-type channels, neuronal L-type channels, and cardiac L-type $\mathrm{Ca}$ channels (Mintz et al., 1991). Block of both L-type and N-type channels with $K_{d}$ values of $\sim 1$ nM suggests that this toxin may recognize a high-affinity binding site shared by $\mathrm{N}$ - and L-type Ca channels and absent in neuronal low-threshold T-type channels. In this article, I have investigated $\omega$-Aga-IIIA block of identified $\mathrm{Ca}$ currents in hippocampal CAl neurons. In addition to blocking $\mathrm{N}$ - and L-type Ca currents, $\omega$-Aga-IIIA produced high-potency block of P-type Ca current and the still unidentified high-threshold $\mathrm{Ca}$ current that remains after maximal block of N-, L-, and P-type Ca currents. The complexity of P-type Ca current block was investigated in cerebellar Purkinje neurons.

\section{Materials and Methods}

Cell preparation. Long-Evans rats 7-15 d old were used for all cell preparations. Purkinje neurons were dissociated from the cerebellar vermis, hippocampal neurons from the CAl region, and dorsal root ganglion (DKG) neurons were isolated from lumbar and cervical ganglia. The protocol is a modified version of the enzyme treatments used by Furshpan and Potter (1989) and Kiskin et al. (1990). Brain tissue was dissected in ice-cold solution containing $82 \mathrm{mM} \mathrm{Na}_{2} \mathrm{SO}_{4}, 30 \mathrm{mM} \mathrm{K}_{2} \mathrm{SO}_{4}$, $5 \mathrm{~mm} \mathrm{MgCl}_{2}, 10 \mathrm{~mm}$ HEPES, $10 \mathrm{~mm}$ glucose, and $0.001 \%$ phenol red indicator ( $\mathrm{pH} 7.4$, adjusted with $\mathrm{NaOH}$ ). Brain tissue was trimmed of meninges and cut in small pieces $\left(\sim 1 \mathrm{~mm}^{3}\right)$, transferred into the same high-Na, high-K solution with $3 \mathrm{mg} / \mathrm{ml}$ protease XXIII (Sigma, St Louis, $\mathrm{MO}$ ), and incubated at $37^{\circ} \mathrm{C}$ for $7-8 \mathrm{~min}$ for central neurons, and 12 15 min for DRG neurons. The tissue was rinsed twice in the high-Na, high-K solution at $37^{\circ} \mathrm{C}$ and transferred to a minimum essential medium solution (GIBCO) containing $10 \mathrm{~mm}$ glucose, $15 \mathrm{~mm}$ HEPES, $1 \mathrm{mg} / \mathrm{ml}$ trypsin inhibitor (Sigma), and $1 \mathrm{mg} / \mathrm{ml}$ bovine serum albumin (Sigma) (pH 7.4, adjusted with $\mathrm{NaOH}$ ). Cells were gently triturated by 20 passages through the tip of a fire-polished Pasteur pipette and kept in the same solution at room temperature for up to $4-6 \mathrm{hr}$. 


\section{CA1 hippocampal neuron}

\section{A T-type current}

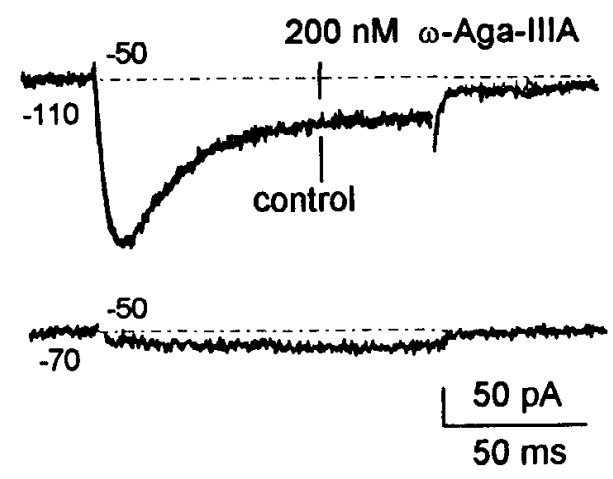

\section{B high-threshold current}

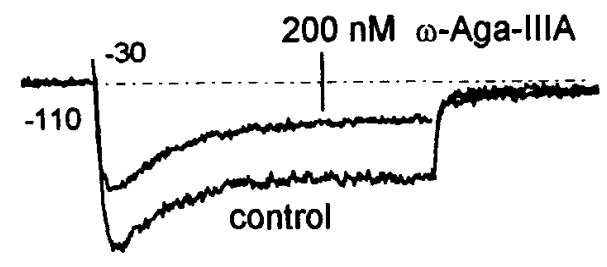

Figure 1. Selective block of high-threshold calcium currents by spider toxin $\omega$-Aga-IIIA in CA1 hippocampal neurons. $A$, Low-threshold T-type current was elicited in isolation by depolarization from $-110 \mathrm{mV}$ to $-50 \mathrm{mV}$ before and after addition of $200 \mathrm{nM} \omega$-Aga-IIIA (upper traces). It was inactivated by holding the cell at $-70 \mathrm{mV}$ for $6 \mathrm{sec}$ (lower trace, recorded in control condition). $B$, In the same cell, high-threshold currents triggered by a depolarization applied from $-110 \mathrm{mV}$ to $-30 \mathrm{mV}$ in control and in the presence of $200 \mathrm{~nm} \omega$-Aga-IIIA.

Purkinje neurons were identified morphologically by their large cell bodies (15-25 $\mu \mathrm{m}$ diameter) with a single dendritic stump; the accuracy of the morphological identification was previously confirmed by labeling of Purkinje neurons with propidium iodide(Regan, 1991). Hippocampal CAl neurons were presumably pyramidal cells based on their distinct morphology. Small-diameter $(<\mathbf{3 0} \mu \mathrm{m})$ DRG neurons were selected for recordings to permit accurate voltage clamp.

Recording technique and drug application. Whole-cell $\mathrm{Ca}^{2+}$ channel currents were recorded with 1.5-7 M $\mathrm{M}$ pipettes made from Boralex glass (Dynalab, Rochester, NY) containing an internal solution of $108 \mathrm{~mm}$ cesium methanesulfonate, $4 \mathrm{~mm} \mathrm{MgCl}_{\text {, }} 9$ mм EGTA, 9 mм HEPES, $4 \mathrm{~mm} \mathrm{Mg-ATP,} 14 \mathrm{~mm}$ creatine phosphate (Tris salt), $0.3 \mathrm{~mm}$ GTP (Tris salt), $\mathrm{pH} 7.4$, adjusted with $\mathrm{CsOH}$. The external solution contained $5 \mathrm{mM} \mathrm{BaCl}_{2}, 160 \mathrm{~mm}$ tetraethylammonium (TEA) $\mathrm{Cl}, 10 \mathrm{mM}$ HEPES, $1 \mathrm{mg} / \mathrm{ml}$ cytochrome $\mathrm{C}$ (Sigma), pH 7.4 with TEA OH. Pipettes were sealed on neurons bathed in Tyrode's solution $(150 \mathrm{~mm} \mathrm{NaCl}, 4 \mathrm{~mm}$ $\mathrm{KCl}, 4 \mathrm{~mm} \mathrm{BaCl}, 2 \mathrm{~mm} \mathrm{CaCl}, 2 \mathrm{~mm} \mathrm{MgCl}$, $10 \mathrm{~mm}$ glucosc, $10 \mathrm{~mm}$ HEPES, pH 7.4 with $\mathrm{NaOH}$ ). Once the seal was established, the cell was transferred into a minichamber containing the $5 \mathrm{~mm} \mathrm{Ba}$ external solution (Mintz et al., 1992b). Drug-containing solutions were applied manually in the minichamber, using a pipettor. Because of the small volume of the minichamber $(\sim 55 \mu \mathrm{l})$, the recorded neuron could be exposed to high concentrations of toxins for long periods of time, using small amounts of toxins. Repetitive (three to six) pipetting in and out the pipette tip ensured a fast mixing of the drug-containing solution with the solution in the minichamber. Occasionally, the time course of current block was biphasic with a fast and a subsequent slow phase. This occurred when the toxin was pipetted close to the cell, which was then exposed transiently to a high toxin concentration. Slightly biphasic time courses (as in Fig. 11) were nevertheless reasonably well fitted with single exponentials.

Stock solutions for drugs were $0.5 \mathrm{~mm} \omega$-conotoxin (Peninsula Laboratories) in the recording $\mathrm{Ba}$ solution, $3 \mathrm{~mm}$ nimodipine (a gift from

\section{A CA1 hippocampal neuron}
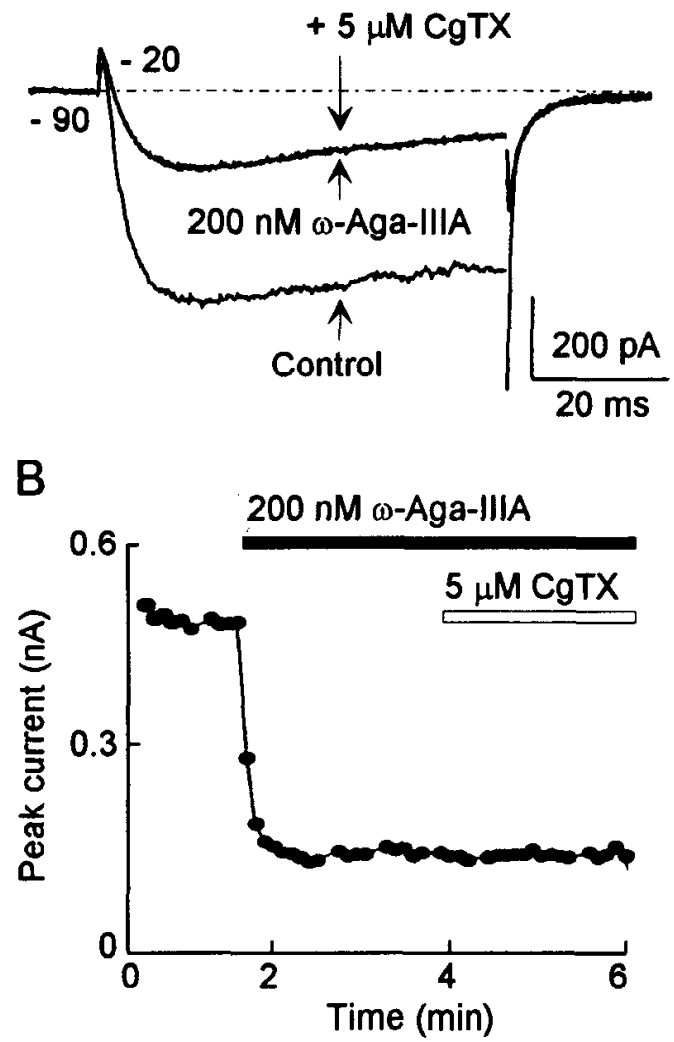

Figure 2. $\omega$-Aga-IIIA occludes $\mathrm{CgTX}$ block of N-type calcium channels in CA 1 hippocampal neurons. $A$, Currents recorded in control, after addition of $200 \mathrm{nM} \omega$-Aga-IIIA, and in the presence of both $200 \mathrm{~nm}$ $\omega$-Aga-IIIA and $5 \mu \mathrm{M}$ CgTX. Ba ( $5 \mathrm{~mm}$ ) current was elicited every $6 \mathrm{sec}$ by voltage steps from $-90 \mathrm{mV}$ to $-20 \mathrm{mV}$. $B$, In the same cell, corresponding time course of the peak Ba current.

Alexander Scriabinc, Miles Laboratories, New Haven, CT) in polyethylene glycol 400, 2-4 mM $\omega$-Aga-IVA and 2-4 mM $\omega$-Aga-IIIA in the recording $\mathrm{Ba}$ solution. The toxins $\omega$-Aga-IVA and $\omega$-Aga-IIIA were a gift from Mike Adams (University of California, Riverside, CA). Drugcontaining stock solutions were stored frozen at $-20^{\circ} \mathrm{C}$.

Electrical recording. Whole-cell currents (Hamill et al., 1981) were recorded using a List EPC-7 amplifier. Currents were elicited and digitized every $50 \mu \mathrm{sec}$ with BASIC-FASTLAB hardware and software (Indec Systems, Sunnyvale, CA). Data were discarded if voltage errors from series resistance remaining after partial compensation were greater than $5 \mathrm{mV}$. Reported potentials were corrected for a liquid junction potential of $-10 \mathrm{mV}$ between the internal solution and the Tyrode's solution in which the pipette current was zeroed before sealing onto the cell membrane. $\mathrm{Ca}^{2+}$ channel currents were corrected for leak and capacitive currents by subtracting a scaled current clicited by a $10 \mathrm{mV}$ hypcrpolarization from $-80 \mathrm{mV}$. In most cells, $\mathrm{Ca}$ channel current ran down slowly with time (by about $5 \%$ per minute or less) and was not corrected for. In a few experiments, as in Figure 11, the control current ran down at a faster rate $(\sim 10 \%$ per min); the fraction of current blocked by each blocker was then normalized to an estimation of the control current value. This value was calculated point by point after the first drug application with the assumption that the rate of rundown is proportional to the current size (Mintz et al., 1992).

Zero time in plots of current amplitude versus time is the time at which current had stabilized after establishment of the seal. All experiments were done at $20-25^{\circ} \mathrm{C}$. Statistical results are given as mean \pm SEM.

Variability in the current components dissected pharmacologically. In neurons with complex mixture of calcium channel types, saturating concentrations of $\mathrm{CgTX}(1-5 \mu \mathrm{M})$, dihydropyridine antagonists (nimodipine or nitrendipine, 2-5 $\mu \mathrm{M}$ ), and $\omega$-Aga-IVA (50-200 nM) block 


\section{A CA1 hippocampal neuron}

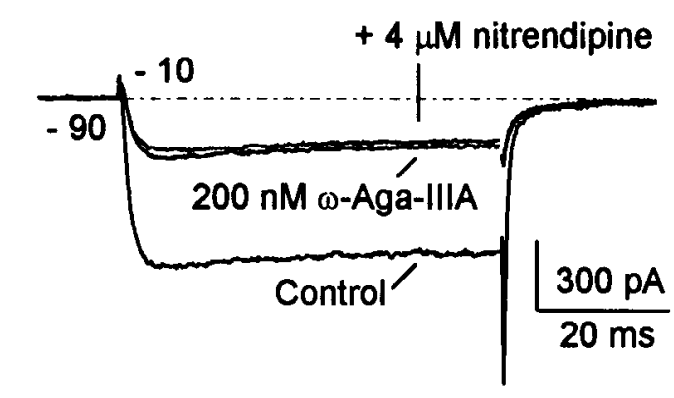

B

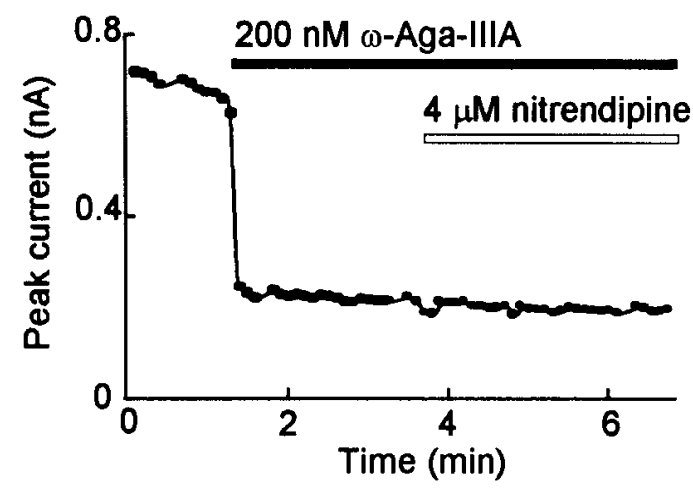

Figure 3. $\omega$-Aga-IIIA occludes nitrendipine inhibition of L-type calcium channels in CA1 hippocampal neurons. $A$, Current recorded in control, in the presence of $200 \mathrm{nM} \omega$-Aga-IIIA, and in the presence of both $\omega$-Aga-IIIA ( $200 \mathrm{nM}$ ) and $4 \mu \mathrm{M}$ nitrendipine. Ba (5 mM) current was elicited every $6 \mathrm{sec}$ by a test pulse from $-90 \mathrm{mV}$ to $-10 \mathrm{mV} . B$, In the same cell, plot of the peak Ba current versus time.

distinct nonoverlapping current components (Mintz et al., 1992b), which can be referred to as $\mathrm{N}$-type (CgTX-sensitive), L-type (dihydropyridinesensitive), and P-type ( $\omega$-Aga-IVA-sensitive) currents. T-type current is defined as the low-threshold transient and slowly deactivating current observed at very negative holding potentials (Carbone and Lux, 1984; Bean, 1985; Fox et al., 1987).

There was significant variability in the amount of currents sensitive to the different blockers in individual CAl neurons. Comparison between components of current blocked by $\omega$-Aga-IIIA, CgTX, and nitrendipine were done using cells from the same batches (total of 30 cells). Estimates of current block by $\omega$-Aga-IVA with or without preblock of current by $\omega$-Aga-IIIA were from 16 cells, also from the same batch of 30 cells. All the numbers presented in this study were from batches of cells in which $\omega$-Aga-IIIA has been tested so that numbers for CgTX, nitrendipine, and $\omega$-Aga-IVA current block do not include cells used in a previous study, in which $\omega$-Aga-IVA but not $\omega$-Aga-IIIA was applied (Mintz et al., 1992b)

Noise analysis. Noise analysis was performed on series of $30-60$ consecutive records of current elicited by 40 -msec-duration step depolarizations applied every second from $-70 \mathrm{mV}$ to $-40 \mathrm{mV}$ using the procedure described in Bean (1985). Currents were filtered at $3 \mathrm{kHz}$. Current variance was calculated point by point from the difference of consecutive sweeps in order to minimize artifactual variance arising from current rundown. Pairs in which the leak current differed by more than $5 \mathrm{pA}$ were discarded from the analysis. The variance during the test pulse was corrected for the background variance by subtracting the variance measured at the holding potential, in the same ensemble of sweeps. The capacitive transient did not change and the control current rundown was less than $2 \%$ over the recording session in the five experiments selected for analysis. Plots of current variance versus mean current were fitted with a linear function with the slope equal to the single channel current.

\section{CA1 hippocampal neuron}

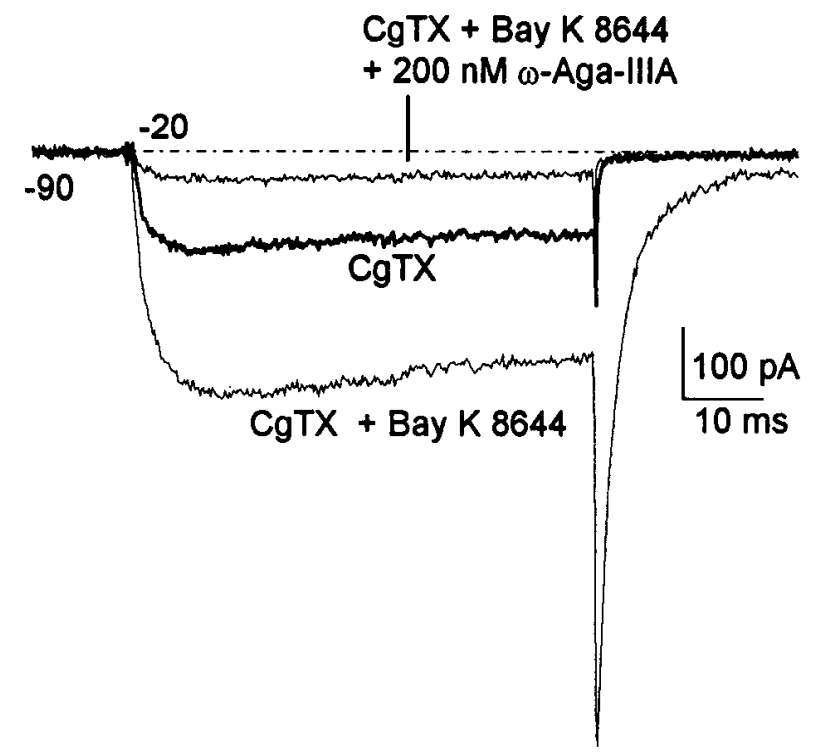

Figure 4. $\quad \omega$-Aga-IIIA abolishes Bay K 8644-enhanced L-type calcium current in CAl hippocampal neurons. Ba $(5 \mathrm{~mm})$ current, elicited every $6 \mathrm{sec}$ by a $60-\mathrm{msec}$-duration step depolarization from $-90 \mathrm{mV}$ to -20 $\mathrm{mV}$, was recorded in the presence of $3 \mu \mathrm{M}$ CgTX (thick trace), with both $\mathrm{CgTX}$ and $3 \mu \mathrm{M}$ Bay K 8644, and finally in the presence of $\mathrm{CgTX}$, Bay $\mathrm{K} 8644$, and $200 \mathrm{~nm} \omega$-Aga-IIIA. This neuron had no low-threshold T-type current.

\section{Results}

Block of N-type and L-type Ca channels by $\omega$-Aga-IIIA in CAl hippocampal neurons

In hippocampal CAl pyramidal cells, as in peripheral neurons (Mintz et al., 1991), $\omega$-Aga-IIIA reduced high-threshold Ca current with no effect on the low-threshold T-type Ca current. In Figure $1 A$, T-type current was elicited in isolation by a depolarization applied from $-110 \mathrm{mV}$ to $-50 \mathrm{mV}$. This current, carried by $5 \mathrm{~mm}$ Ba (as for all experiments), was identified as low-threshold $\mathrm{T}$-type by its rapid inactivation during the test pulse, its slowly deactivating tail current upon repolarization to $-110 \mathrm{mV}$, and its almost complete inactivation when the cell was held at $-70 \mathrm{mV}$ (lower trace, Fig. $1 A$ ). In this cell as in five other CA1 neurons, $200 \mathrm{nM} \omega$-Aga-IIIA blocked a fraction of the high-threshold $\mathrm{Ca}$ current (Fig. $1 B$ ) with no effect on T-type current. Block of high-threshold current was always partial. In 14 other CA1 pyramidal cells with no detectable T-type current, 200 nм $\omega$-Aga-IIIA blocked the overall high-threshold Ca channel current by $70 \pm 4 \%$. Toxin concentrations greater than $100 \mathrm{~nm}$ produced maximal current block; the same current fraction remained unblocked when $\omega$-Aga-IIIA concentration was increased from $100 \mathrm{~nm}$ to $200 \mathrm{~nm}$ (not shown).

In subsequent experiments, I used blockers or agonists of the different high-threshold $\mathrm{Ca}$ channel types to identify which $\mathrm{Ca}$ channels are targeted by $\omega$-Aga-IIIA.

$\mathrm{CgTX}$, at saturating concentrations, normally blocks $\sim 30$ $40 \%$ of the high-threshold Ca current in CA1 hippocampal neurons (Regan et al., 1991; Mintz et al., 1992b). In the batch of cells used for this series of experiments, CgTX blocked $35 \pm$ $4 \%(n=15)$. Yet, when application of $5 \mu \mathrm{M} \mathrm{CgTX} \mathrm{was} \mathrm{con-}$ secutive to the application of $200 \mathrm{~nm} \omega$-Aga-IIIA (Fig. 2), CgTX had no effect on the high-threshold $\mathrm{Ca}$ current of CAl neurons 
A CA1 hippocampal neuron

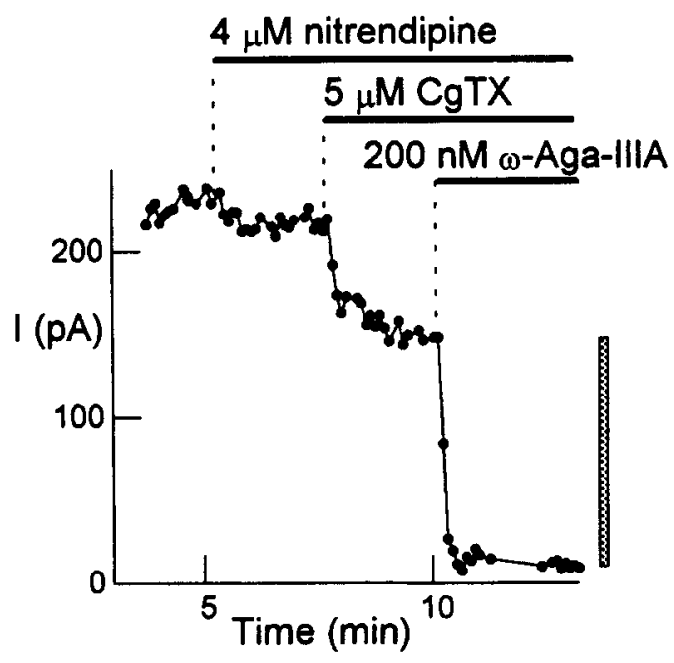

B

$200 \mathrm{nM} \omega$-Aga-IIIA
after $\mathrm{CgTX}$ and Nitr.

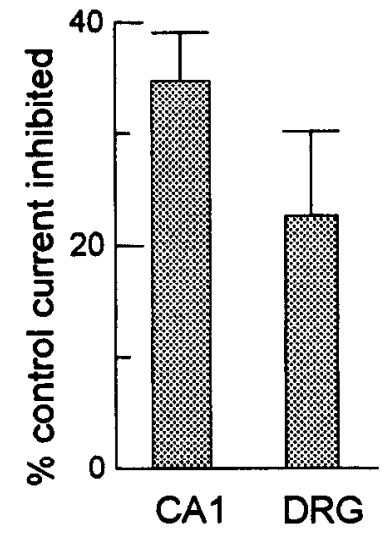

Figure 5. High-threshold $\mathrm{Ca}$ channels other than L-, and N-type channels are blocked by $\omega$-Aga-IIIA. $A$, In a CAl hippocampal neuron, time course of the peak $\mathrm{Ba}(5 \mathrm{~mm})$ current in control, in the presence of $4 \mu \mathrm{M}$ nitrendipine, with both $4 \mu \mathrm{M}$ nitrendipine and $5 \mu \mathrm{M} \mathrm{CgTX}$, and with the three blockers, $4 \mu \mathrm{M}$ nitrendipine, $5 \mu \mathrm{M} \mathrm{CgTX}$, and $200 \mathrm{~nm}$ $\omega$-Aga-IIIA. Current was elicited every $6 \mathrm{sec}$ by a $60 \mathrm{msec}$ depolarization from $-90 \mathrm{mV}$ to $-10 \mathrm{mV} . B$, In rat DRG neurons ( $n=5$, left bar) and CA1 hippocampal neurons $(n=6$, right bar), current inhibition produced by $200 \mathrm{~nm}$ $\omega$-Aga-IIIA when it was applied after preblock of $\mathrm{N}$ - and $\mathrm{L}$-type Ca channels with saturating concentrations of $\mathrm{CgTX}$ $(2-5 \mu \mathrm{M})$ and nitrendipine $(2-5 \mu \mathrm{M})$.
( $n=3$ ), suggesting that $\omega$-Aga-IIIA blocks CgTX-sensitive N-type Ca channels.

Dihydropyridine antagonists normally reduce CAl neuron high-threshold $\mathrm{Ca}$ current by $\sim 20-30 \%$ (Regan et al., 1991; Mintz et al., 1992a). In this experimental series, nitrendipine blocked $16 \pm 3 \%(n=13)$ of the control current. In Figure 3 , block of L-type channels by $4 \mu \mathrm{M}$ nitrendipine was prevented by a previous application of $200 \mathrm{nM} \omega$-Aga-IIIA $(n=4)$, suggesting that $\omega$-Aga-IIIA also blocks L-type Ca channels. Direct evidence for $\omega$-Aga-IIIA block of L-type Ca channels was obtained using the dihydropyridine agonist Bay K 8644. In the experiment of Figure 4, N-type Ca current was suppressed with

\section{CA1 hippocampal neurons}

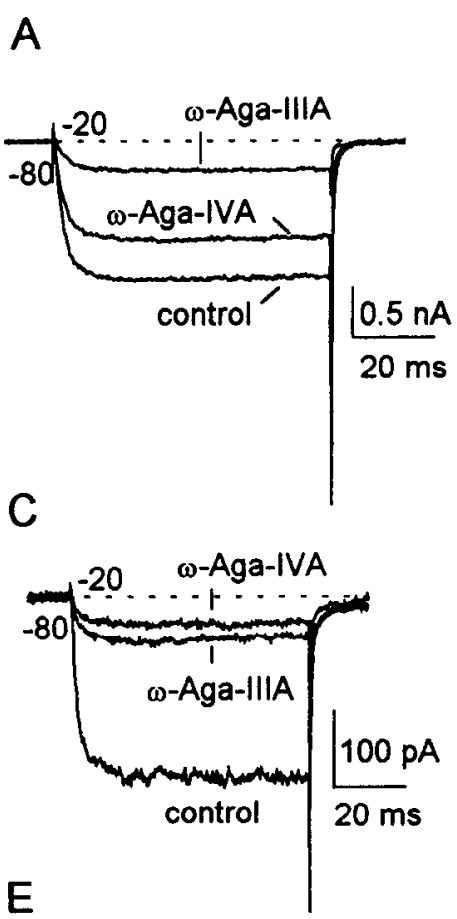

$\%$ control current inhibited

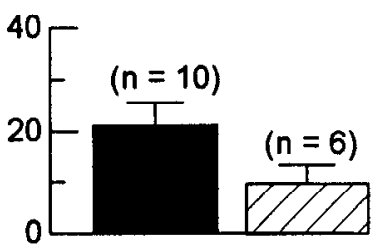

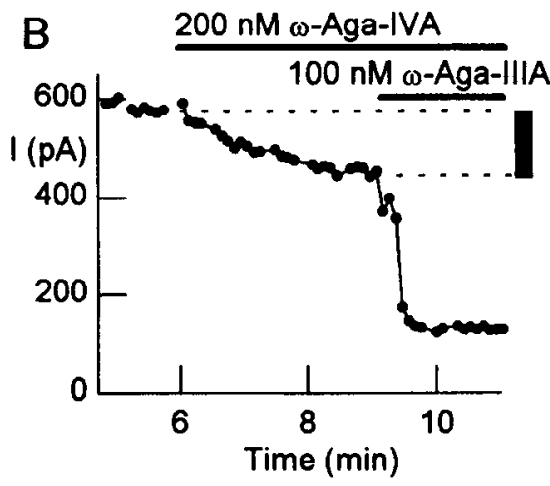

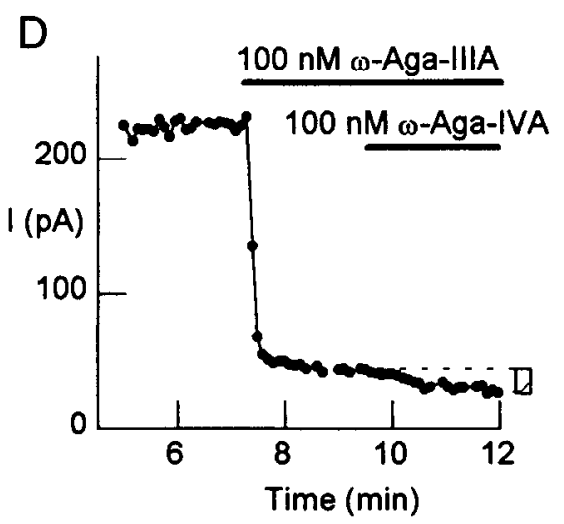

$\omega$-Aga-IVA alone

$\omega$-Aga-IVA

after $\omega$-Aga-IIIA
Figure 6. $\omega$-Aga-IIIA reduces but does not prevent block of P-type channels by spider toxin $\omega$-Aga-IVA in CAl hippocampal neurons. $A, \mathrm{Ba}(5 \mathrm{~mm})$ currents recorded in a cell in which 200 nM $\omega$-Aga-IVA was applicd first. After $3 \mathrm{~min}$, the second toxin, $\omega$-Aga-IIIA $(100 \mathrm{nM})$, was then applied together with $200 \mathrm{~nm} \omega$-Aga-IVA. $B$, In the same cell, corresponding time course. $C$, Ba currents recorded in another cell in which $100 \mathrm{nM} \omega$-Aga-IIIA was administered first. The second toxin, $\omega$-Aga-IVA (100 nM), was then applied together with 100 nM $\omega$-Aga-IIIA. $D$, In the same cell as in $C$, corresponding time course. $E$ Current inhibited by $\omega$-Aga-IVA in 10 cells in which $\omega$-Aga-IVA was applied first (as in $A$ and $B$ ) and in six other cells in which $\omega$-Aga-IVA was applicd second to $\omega$-Aga-IIIA (as in $C$ and $D$ ). Current is expressed as percentage of the control current before application of toxins. 


\section{CA1 hippocampal neuron}

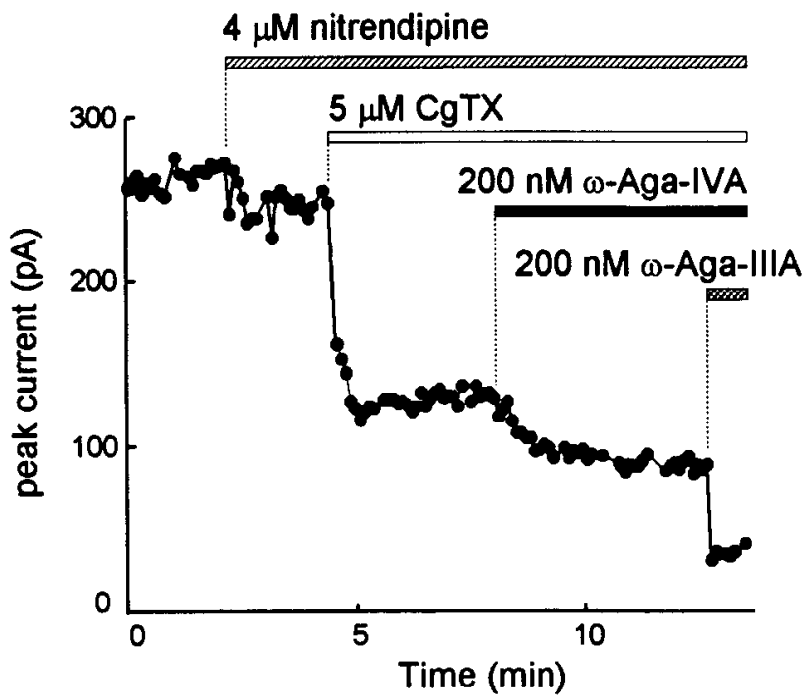

Figure 7. $\omega$-Aga-IIIA blocks high-threshold calcium currents that are insensitive to blockers of $\mathrm{N}$-, L-, and P-type calcium channels: in a CA1 hippocampal neuron, time course of the peak Ba current elicited by 60 msec test depolarizations, applied every $6 \mathrm{sec}$, from $-80 \mathrm{mV}$ to -20 $\mathrm{mV}$, during cumulative application of $4 \mu \mathrm{M}$ nitrendipine, $5 \mu \mathrm{M} \mathrm{CgTX}$, $200 \mathrm{nM} \omega$-Aga-IIIA, and $200 \mathrm{nM} \omega$-Aga-IIIA. The dotted lines indicate the onset of application of the different blockers.

$3 \mu \mathrm{M}$ CgTX. Bay K 8644, which prolongs the openings of L-type Ca channels (Hess et al., 1984; Nowycky et al., 1985b), more than doubled the macroscopic current elicited during a test depolarization to $-20 \mathrm{mV}$ and slowed the deactivation of L-type current upon repolarization to $-90 \mathrm{mV}$. This slowly deactivating tail current, carried through L-type $\mathrm{Ca}$ channels, was abolished by $200 \mathrm{nM} \omega$-Aga-IIIA, as was most of the test pulse current. These data confirm that $\omega$-Aga-IIIA blocks high-threshold L-type and N-type Ca currents, but not low-threshold T-type current, in central neurons.

\section{$\omega$-Aga-IIIA blocks high-threshold Ca channels other than L-type and $N$-type $C a$ channels}

In CA1 hippocampal neurons, the amount of current blocked by $\omega$-Aga-IIIA alone $(\sim 70 \%)$ is not very different from the total amount of current carried through $N$-type ( $~ 30-40 \%)$ and L-type ( 20-30\%) Ca channels (Regan et al., 1991; Mintz et al., 1992b). In rat DRG neurons, too, the $65 \%$ current fraction inhibited by $\omega$-Aga-IIIA (Mintz et al., 1991) is similar to the $\sim 60-70 \%$ current fraction carried through $\mathrm{N}$ - and L-type channels (Regan et al., 1991; Mintz et al., 1992b). These numbers suggest that $\omega$-Aga-IIIA might mainly target $\mathrm{N}$-, and L-type $\mathrm{Ca}$ channels. To test this hypothesis, I studied the effect of $\omega$-Aga-IIIA on currents insensitive to $\mathrm{N}$ - and L-type channel blockers in both DRG and hippocampal CA1 neurons. Unexpectedly, $\omega$-AgaIIIA did produce a significant reduction in the high-threshold Ca current (Fig. 5) when it was applied after preblock of L-type and $\mathrm{N}$-type current with $4 \mu \mathrm{M}$ nitrendipine and $5 \mu \mathrm{M} \mathrm{CgTX}$. In CA1 neurons, $\omega$-Aga-IIIA blocked $\sim 70 \%$ of the current unaffected by $\mathrm{CgTX}$ and nitrendipine. This current component represented $35 \pm 4 \%(n=6)$ of the overall control current. In DRG neurons, $\omega$-Aga-IIIA blocked $\sim 60 \%$ of the current resistant to CgTX and nitrendipine, which amounted to $23+7 \%$ $(n=5)$ of the control current. $\omega$-Aga-IIIA must block other

\section{Cerebellar Purkinje neuron}

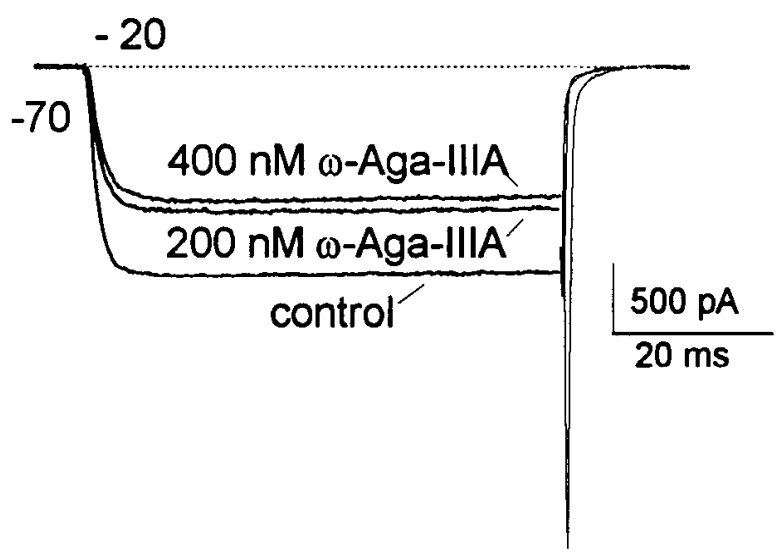

Figure 8. Saturating concentrations of $\omega$-Aga-IIIA partially block highthreshold calcium current in Purkinje neurons: in the same cell, current records in control conditions, after addition of $200 \mathrm{nM} \omega$-Aga-IIIA and increase of $\omega$-Aga-IIIA concentration to $400 \mathrm{~nm}$.

high-threshold $\mathrm{Ca}$ channels besides $\mathrm{CgTX}$-sensitive $\mathrm{N}$-type and dihydropyridine-sensitive L-type $\mathrm{Ca}$ channels.

Are these channels P-type Ca channels? Occlusion experiments between $\omega$-Aga-IIIA and the selective P-type Ca channel blocker $\omega$-Aga-IVA addressed this question. In $10 \mathrm{CAl}$ hippocampal cells (as in Fig. 6A,B), 100-200 nM $\omega$-Aga-IVA was applied first and blocked $21 \pm 4 \%$ of the current elicited at -20 or $-10 \mathrm{mV}$ (Fig. $6 E$ ). In six other experiments using the same three batches of cells, 100-200 nM $\omega$-Aga-IVA was applied after $\omega$-Aga-IIIA application (as in Fig. 6C,D); it then blocked a smaller current fraction, which amounted to $10 \pm 4 \%$ of the overall control current. These results suggest that $\omega$-Aga-IIIA occludes $\omega$-Aga-IVA block of P-type Ca channels partially, by about $50 \%$.

\section{Partial block of a high-threshold Ca current resistant to} blockers of $L-, N$-, and P-type channels

In most central neurons, a significant component of the highthreshold current is unaffected by combined applications of saturating concentrations of $\mathrm{CgTX}$, dihydropyridines, and $\omega$-AgaIVA (Mintz el al., 1992b), which suggests that other high-threshold Ca channels may exist in addition to the $\mathrm{N}$-, L-, and P-type $\mathrm{Ca}$ channels already described. Occasionally, this current represented up to $30 \%$ of the overall high-threshold current; it was then possible to quantify its sensitivity to $\omega$-Aga-IIIA. In all of these experiments as in Figure 7, the current remaining in the presence of $\mathrm{CgTX}$, nitrendipine, and $\omega$-Aga-IVA was partially blocked by $200 \mathrm{nM} \omega$-Aga-IIIA. In four CAl hippocampal neurons in which $25 \pm 4 \%$ of the overall current remained after block of N-, L-, and P-type Ca channels, $76 \pm 13 \%$ of that current was blocked by $\omega$-Aga-IIIA (a fraction representing 19 $\pm 4 \%$ of the control current). In five CA3 hippocampal neurons in which $29 \pm 7 \%$ of the control current was unaffected after block of N-, L-, and P-type Ca channels, $71 \pm 7 \%$ of this current was blocked by $\omega$-Aga-IIIA (a fraction representing $21 \pm 6 \%$ of the control current). Similar data were obtained in a spinal cord interneuron and a cortical pyramidal cell, in which $\omega$-Aga-IIIA blocked respectively $65 \%$ and $90 \%$ of the current remaining in the presence of saturating concentrations of $\mathrm{CgTX}$, nitrendipine, and $\omega$-Aga-IVA. 


\section{Purkinje neuron}

A

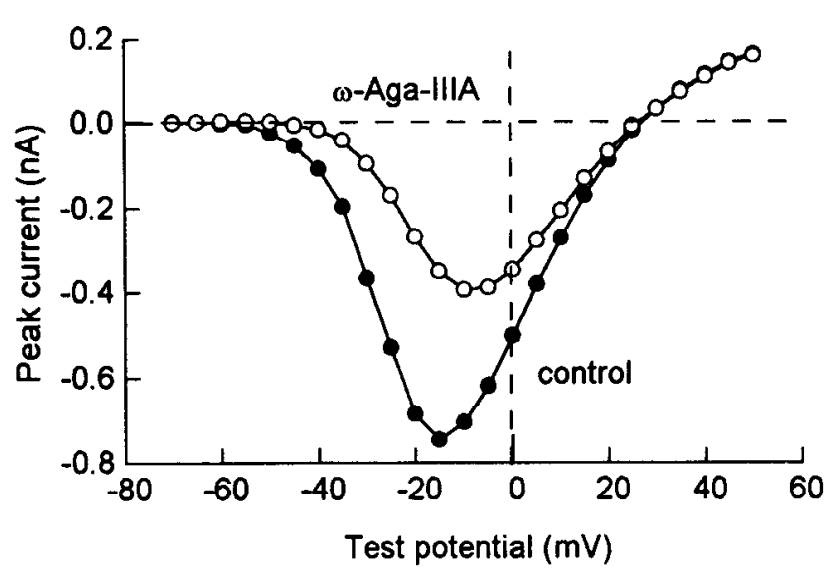

B

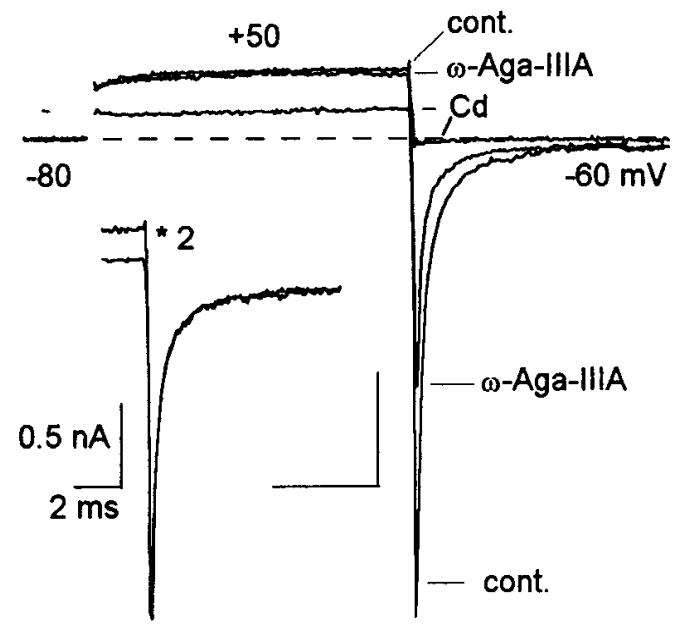

C

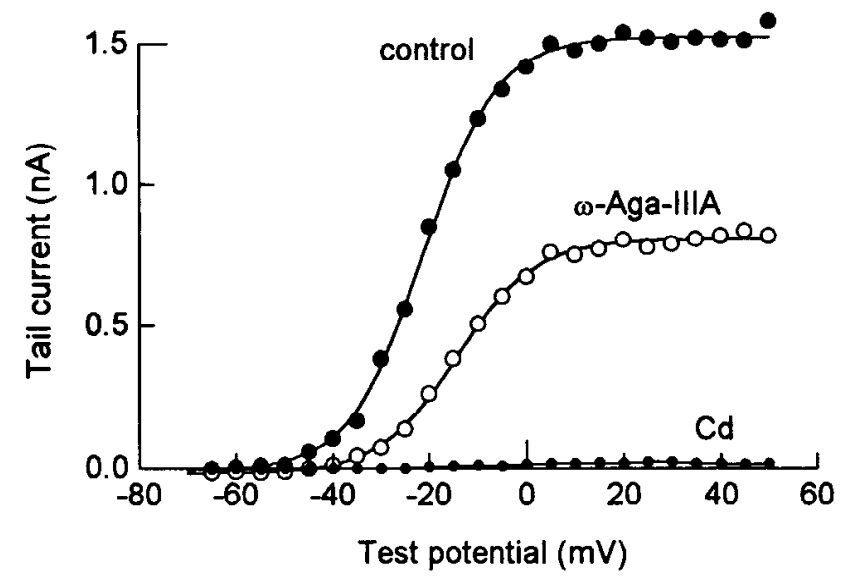

D

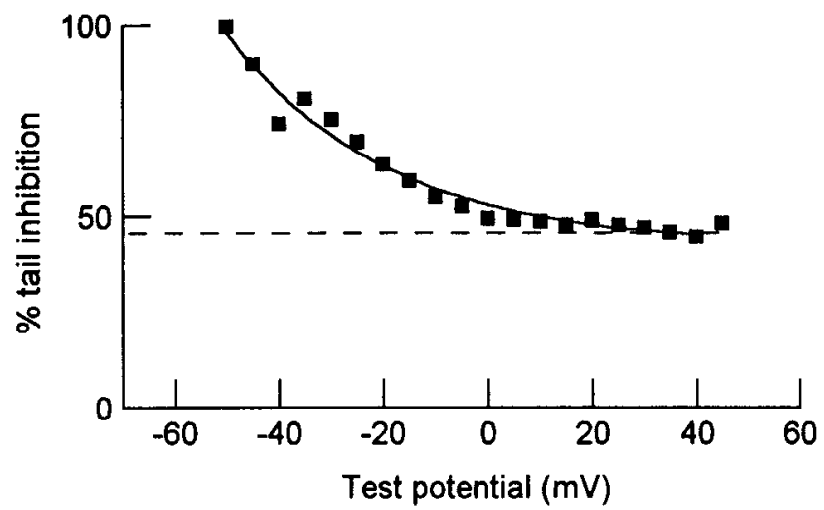

Figure 9. Voltage dependence of P-type current block by $\omega$-Aga-IIIA in a Purkinje neuron. A, Current-voltage relationship for P-type current in control condition, that is, in the presence of $5 \mu \mathrm{M}$ nimodipine and $3 \mu \mathrm{M}$ CgTX (solid circles), and in the presence of $5 \mu \mathrm{M}$ nimodipine, $3 \mu \mathrm{M}$ CgTX, and $200 \mathrm{nM} \omega$-Aga-IIIA (open circles). Peak currents were measured during $60 \mathrm{msec}$ depolarizations applied from a holding potential of $-80 \mathrm{mV}$ to various test potentials. $B$, In the same cell, currents elicited by a test pulse applied from $-80 \mathrm{mV}$ to $+50 \mathrm{mV}$, in control condition, after addition of $200 \mathrm{nM} \omega$-Aga-IIIA and of $50 \mu \mathrm{M} \mathrm{Cd}$. The tail currents were recorded at $-60 \mathrm{mV}$. The inset illustrates in the same experiment current in control and after addition of $\omega$-Aga-IIIA after scaling by a factor of 2 the current recorded in the presence of $\omega$-Aga-IIIA (same calibration in $B$ and $i n s e t$ ). $C$, Activation curves, in the same cell, before and after addition of $200 \mathrm{~nm} \omega$-Aga-IIIA, and in the presence of $50 \mu \mathrm{M} C \mathrm{Cd}$. The data represent the tails currents recorded at $-60 \mathrm{mV}$ following depolarizations to various test potentials (same voltage protocols as in $A$ and $B$ ). The data in control and after addition of $\omega$-Aga-IIIA were fitted with Boltzmann curves of the form $I_{\max } /\left[1+\exp -\left(V-V_{0.5}\right) / k\right]$ where $I_{\max }$ (the maximal tail current), $V_{0.5}$ (the midpoint), and $k$ (the slope factor) were, respectively, $1.5 \mathrm{nA},-21 \mathrm{mV}$, and $7.5 \mathrm{mV}$ in control and $0.78 \mathrm{nA},-14 \mathrm{mV}$, and $8 \mathrm{mV}$ in the prescnce of $\omega$-Aga-IIIA. $D, \omega$ - $\Lambda$ ga-IIIA inhibition of the tail currents (expressed as percentage of the control values) was voltage dependent and varied with the magnitude of the test depolarization. In this cell, the uncompensated series resistance was $1.1 \mathrm{M} \Omega$, which produced a voltage error of $\sim 0.8 \mathrm{mV}$ at the peak of the $I / V$ relationship and of $1.7 \mathrm{mV}$ for the larger tail currents. Nimodipine $(3 \mu \mathrm{M})$ and $\mathrm{CgTX}(3 \mu \mathrm{M})$ were present throughout the experiment.

\section{Partial block of Purkinje neuron P-type Ca current}

The block of P-type Ca channels by $\omega$-Aga-IIIA was studied in more detail in cerebellar Purkinje neurons, in which $\sim 90 \%$ of the high-threshold current is carried through P-type $\mathrm{Ca}$ channels. In Purkinje neurons, $200 \mathrm{~nm} \omega$-Aga-IIIA blocked the overall high-threshold $\mathrm{Ca}$ current incompletely (Fig. 8). Increasing the toxin concentration to $400 \mathrm{~nm}$ had no additional effect on current block, showing that maximally effective doses of $\omega$-AgaIIIA only produced partial block of Purkinje neuron highthreshold Ca current. Partial block of P-type current was also observed in experiments performed in the continuous presence of CgTX and nimodipine to suppress the small fraction of current $(\sim 10 \%)$ carried through $\mathrm{N}$ - and L-type Ca channels in Purkinje neurons (Figs. 9, 10).

P-type current block by $\omega$-Aga-IIIA was voltage dependent (Fig. 9). The peak of the current-voltage relationship was shifted by about $+7 \mathrm{mV}$ in three cells in which voltage errors due to incomplete series resistance compensation were less than $1 \mathrm{mV}$ (Fig. 9A). $\omega$-Aga-IIIA reduced current elicited by small depolarizations to a large extent, whereas Cd-sensitive outward current, carried by internal $\mathrm{Cs}$ ions during big depolarizations, was little affected by $\omega$-Aga-IIIA (Fig. 9B). The transition between most channels being blocked at the negative holding potential 


\section{Purkinje neuron}

Figure 10. $\omega$-Aga-IIIA altered P-type current instantaneous current-voltage relationship. A 1 msec test pulse to +60 $\mathrm{mV}$ was used to activate P-type current maximally. Instantaneous tail currents observed at various potentials were measured $300 \mu \mathrm{sec}$ after repolarization from $+60 \mathrm{mV}$. The data points represent tail currents versus membrane potential in control (solid circles), after addition of $200 \mathrm{nM} \omega$-Aga-IIIA (open circles), and after subsequent application of $50 \mu \mathrm{M}$ Cd (small circles). The inset illustrates current relaxations at $+160 \mathrm{mV}$ (upper traces) and $-50 \mathrm{mV}$ (lower traces) in the same experiment. The whole experiment was done in the presence of $3 \mu \mathrm{M} \mathrm{CgTX}$ and $3 \mu \mathrm{M}$ nimodipine.

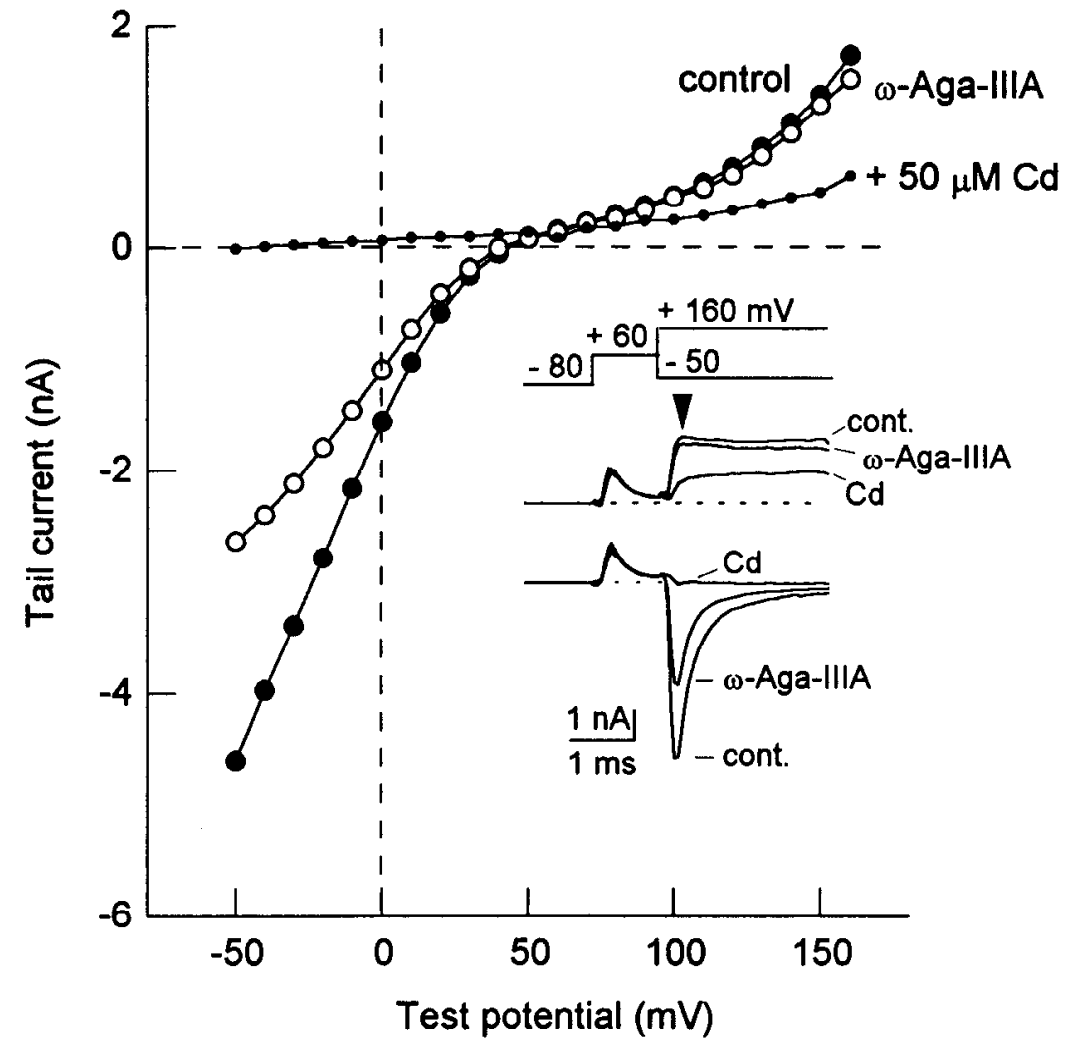

to most being unblocked at potentials greater than $+20 \mathrm{mV}$ occurred in less than $300 \mu \mathrm{sec}$. In contrast, tail currents elicited upon repolarization to $-60 \mathrm{mV}$ were inhibited at all test pulse potentials (Fig. 9C). $\omega$-Aga-IIIA did not alter the kinetics of the deactivating tail currents (Fig. $9 B$, inset). Yet, the magnitude of tail current inhibition varied with test pulse potentials (Fig. $9 D$ ). Block of tail current was almost complete after small depolarizations (test potentials between -50 and $-40 \mathrm{mV}$ at the foot of the activation curve), but the tail current inhibition decreased with increasing test depolarizations; at positive large test potentials, tail currents were reduced only by $\sim 50 \%$, independent of voltage.

$\omega$-Aga-IIIA also altered the instantaneous P-type currentvoltage relationship in a voltage-dependent manner (Fig. 10). Instantaneous tail currents at various membrane potentials were measured after a 1 msec test pulse to $+60 \mathrm{mV}$. This brief depolarization is sufficient for maximal activation of P-type $\mathrm{Ca}$ current in control conditions, since an increase in its duration or amplitude did not change the subsequent tail currents (not shown). $\omega$-Aga-IIIA reduced Ba-carried inward tail currents to a larger extent than the Cd-sensitive outward currents carried by $\mathrm{Cs}$ ions through $\mathrm{Ca}$ channels. The tail current at $-50 \mathrm{mV}$ was reduced by $40 \pm 2 \%(n=3)$, while the Ca channel tail current at $+150 \mathrm{mV}$ was blocked by only $11 \pm 1 \%(n=3)$.

Interestingly, $\omega$-Aga-IIIA did not interfere with the ability of $\omega$-Aga-IVA to block P-type current completely (Fig. 12). The fraction of P-type current left in the presence of $200 \mathrm{nM} \omega$-AgaIIIA was abolished by $100 \mathrm{~nm} \omega$-Aga-IVA at all test pulse potentials (Fig. 12A). In the presence of $\omega$-Aga-IIIA (Fig. 12B), $\omega$-Aga-IVA block of P-type current still occurred with fast ki- netics and could be relieved by depolarization, as in control conditions (Mintz et al., 1992b).

$\omega$-Aga-IVA-sensitive P-type Ca channels may consist of two classes of channels, one blocked by $\omega$-Aga-IIIA, the other completely insensitive to $\omega$-Aga-IIIA. Alternatively, $\omega$-Aga-IVAsensitive $P$-type channels may be an homogeneous population of channels, all of them being sensitive to $\omega$-Aga-IIIA but partially blocked by $\omega$-Aga-IIIA. In this case, $\omega$-Aga-IIIA might decrease the single-channel current. To test this, noise analysis was performed in five Purkinje cells, all recorded in the continuous presence of $3 \mu \mathrm{M} \mathrm{CgTX}$ and $2 \mu \mathrm{M}$ nitrendipine. Current was elicited by small depolarization to $-40 \mathrm{mV}$, which corresponds to the foot of the activation curve (Fig. 9C). Plots of current variance versus mean current were fitted with linear relationships, whose slopes provided an estimate for the singlechannel current before and after addition of $\omega$-Aga-IIIA (not shown). In these five cells, $200 \mathrm{nM} \omega$-Aga-IIIA reduced the mean current to $39 \pm 11 \%$ and the single-channel current to $66 \pm 6 \%$ of the control values $(0.25 \pm 0.06 \mathrm{pA}$ in control, $0.18 \pm 0.02$ pA in the presence of $\omega$-Aga-IIIA). These data are consistent with $\omega$-Aga-IIIA affecting all P-type channels by reducing their single-channel current, but they are also consistent with selective block of a distinct population of channels with a larger unitary current than the channels remaining unblocked.

\section{Discussion}

This study shows that $\omega$-Aga-IIIA blocks pharmacologically identified L-type, N-type, and P-type Ca currents in CAl hippocampal neurons, with no effect on low-threshold T-type $\mathrm{Ca}$ currents. $\omega$-Aga-IIIA-block of P-type Ca current investigated in 


\section{Cerebellar Purkinje neuron}

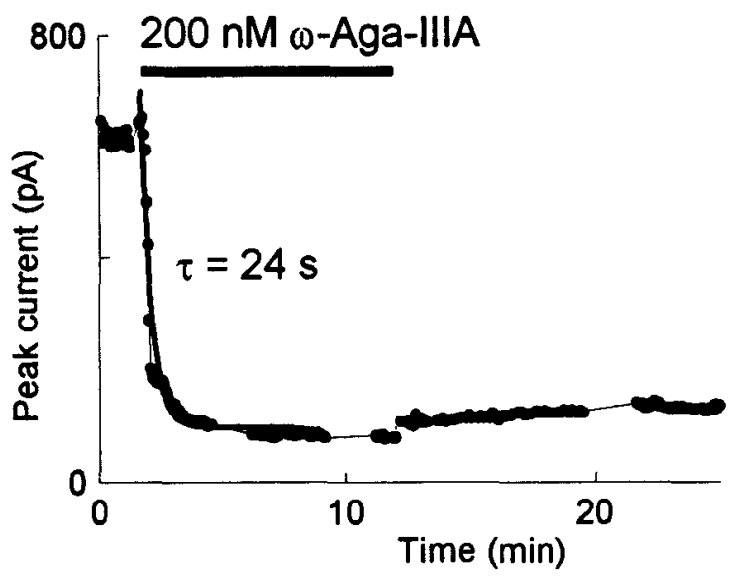

Figure 11. Kinetics of P-type current block by $\omega$-Aga-IIIA. Current, elicited by $60 \mathrm{msec}$ depolarizations applied from $-70 \mathrm{mV}$ to $-40 \mathrm{mV}$ every $6 \mathrm{sec}$, was recorded in control conditions, in the presence of 200 nM $\omega$-Aga-IIIA, and during washout of the toxin. The time course for current block was fitted with a single exponential with a time constant of $24 \mathrm{sec}$.

cerebellar Purkinje neurons was incomplete, voltage dependent, and accompanied by a reduction of P-type single-channel current as determined with noise analysis. In addition, the still unidentified current that is resistant to $\mathrm{CgTX}$, dihydropyridines, and $\omega$-Aga-IVA was partially blocked by $\omega$-Aga-IIIA in a variety of central neurons.

\section{$\omega$-Aga-IIIA block of identified high-threshold Ca currents}

$\omega$-Aga-IIIA block of L-type Ca current was investigated in CA1 hippocampal neurons. L-type Ca current block was complete and showed no obvious voltage dependence. Channels modified by dihydropyridine agonists were still sensitive to $\omega$-Aga-IIIA, suggesting that dihydropyridines and $\omega$-Aga-IIIA act at distinct hinding sites. These data are consistent with previous results showing that $\omega$-Aga-IIIA completely suppresses L-type Ca channels in rat DRG neurons and cardiac cells, with the same high potency $\left(K_{d} \sim 0.5 \mathrm{nM}\right)$ at all membrane potentials, whether or not the dihydropyridine agonist Bay K 8644 is present (Mintz et al., 1991; Cohen et al., 1992).

In contrast to L-type $\mathrm{Ca}$ current, other high-threshold $\mathrm{Ca}$ currents appear to be only partially blocked by $\omega$-Aga-IIIA.

$\omega$-Aga-IIIA partial block of P-type Ca current was primarily investigated in cerebellar Purkinje neurons. In the presence of $\omega$-Aga-IIIA, the remaining P-type current was still abolished by $100 \mathrm{~nm} \omega$-Aga-IVA, suggesting that the two spider toxins act at independent sites. In hippocampal CAl neurons, incomplete block is inferred from the fact that $\omega$-Aga-IIIA only partially occluded the blockade of P-type current by $\omega$-Aga-IVA (by $50 \%$ at -20 or $-10 \mathrm{mV}$ ).

Current block by $\mathrm{CgTX}$ is prevented by $\omega$-Aga-IIIA in hippocampal $\mathrm{CA} 1$, indicating that $\omega$-Aga-IIIA either blocks CgTXsensitive channels or occludes $\mathrm{CgTX}$ binding site. $\omega$-Aga-IIIA does prevent $\mathrm{CgTX}$ binding to chick brain synaptosomal membranes (Venema et al., 1992). Does it block N-type channels? $\omega$-Aga-IIIA alone blocked $\sim 70 \%$ of the control current in CA 1 neurons. This is comparable to the sum $(-80 \%)$ of current com-

\section{Purkinje neurons}

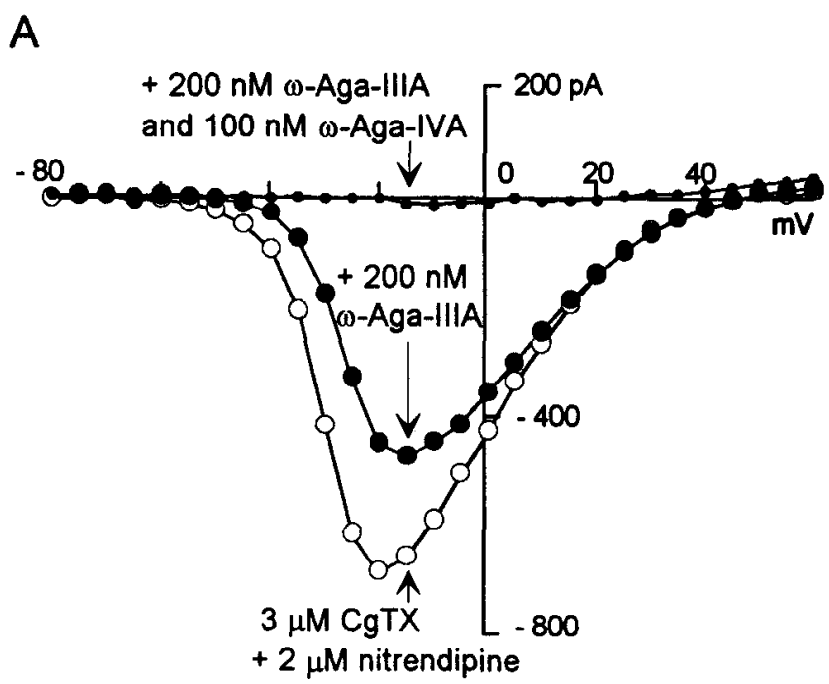

8

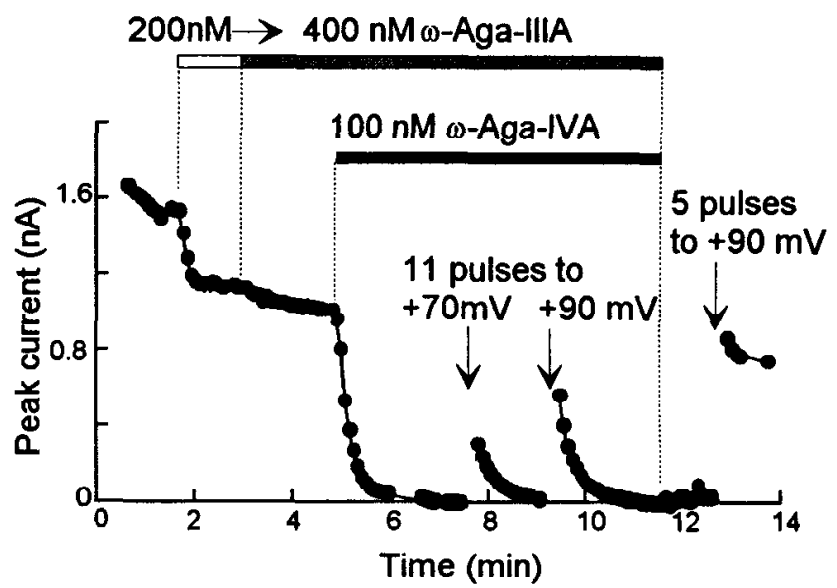

Figure 12. Independent block of P-type current by the toxins $\omega$-AgaIIIA and $\omega$-Aga-IVA. $A$, P-type current remaining in the presence of saturating concentration of $\omega$-Aga-IIIA was abolished at all test potentials by $100 \mathrm{nM} \omega$-Aga-IVA. Plots represent current-voltage relationships for P-type current in control conditions, in the presence of 200 nM $\omega$-Aga-IIIA and after addition of both $200 \mathrm{nM} \omega$-Aga-IIIA and 100 nM $\omega$-Aga-IVA. Nitrendipine $(2 \mu \mathrm{M})$ and $\mathrm{CgTX}(3 \mu \mathrm{M})$ were present throughout the experiment. In this cell, the uncompensated series resistance was $6 \mathrm{M} \Omega$, leading to a $\sim 4.2 \mathrm{mV}$ voltage error at the peak of the current-voltage curve. $B$, In the presence of $\omega$-Aga-IIIA, large depolarizations still alleviated $\omega$-Aga-IVA block of P-type current. In this Purkinje cell (same cell as in Fig. 8), Ba (5 mM) current elicited every $6 \mathrm{sec}$ by a $60 \mathrm{msec}$ depolarization from $-70 \mathrm{mV}$ to $-20 \mathrm{mV}$ was recorded in the presence of $200 \mathrm{nM} \omega$-Aga-IIIA, after an increase of $\omega$-Aga-IIIA concentration to $400 \mathrm{nM}$, and in the presence of both 400 nM $\omega$-Aga-IIIA and $100 \mathrm{nM} \omega$-Aga-IVA. The right dotted line indicates the onset for toxin washout. The normal pulse protocol was interrupted on three occasions (see arrows) by a train of $60 \mathrm{msec}$ depolarizations from $-70 \mathrm{mV}$ to $+70 \mathrm{mV}$ or $+90 \mathrm{mV}$, applied every $500 \mathrm{msec}$.

ponents sensitive to CgTX $(\sim 35 \%)$, dihydropyridine $(\sim 16 \%)$, both $\omega$-Aga-IVA and $\omega$-Aga-IIIA ( 10\%), together with the $20 \%$ current component sensitive to $\omega$-Aga-IIIA and carried through unidentified high-threshold Ca channels. Thus, $\omega$-Aga-IIIA blocks a substantial fraction of the $35 \%$ current component carried through $\mathrm{N}$-type channels. There is some uncertainty as 
to the exact degree of block. The $10 \%$ difference leaves open the possibility that $\omega$-Aga-IIIA may block only $\sim 70 \%$ of N-type $\mathrm{Ca}$ channels in CA1 neurons as it does for N-type Ca current in frog sympathetic neurons (Boland et al., 1992).

Current components resistant to N-, L-, and P-type Ca channel blockers were incompletely blocked by $\omega$-Aga-IIIA in CAI neurons, as well as in DRG, cortical, and spinal cord neurons. Since there are examples of neurons and excitable cells (some sympathetic neurons, Purkinje neurons, and cardiac cells) in which high-threshold currents are abolished by $(1-3 \mu \mathrm{M}) \mathrm{CgTX}$, (2-5 $\mu$ M) nitrendipine, and (50-200 nM) $\omega$-Aga-IVA, it seems reasonable to think that saturating concentrations of these blockers do block L-, N-, and P-type Ca currents completely and that the currents left in the presence of the three blockers are carried through $\mathrm{Ca}$ channels other than $\mathrm{N}$-, L-, and P-type $\mathrm{Ca}$ channels. It remains to be investigated whether such currents are homogeneous and partially blocked by $\omega$-Aga-IIIA or heterogeneous with components having different sensitivities to $\omega$-Aga-IIIA.

\section{Partial block of P-type Ca current in Purkinje neurons}

The complexity of $\omega$-Aga-IIIA block of P-type Ca current is apparent in Purkinje neurons. A simple hypothesis considers an homogeneous population of $P$-type Ca channels, all sensitive to $\omega$-Aga-IIIA and partially blocked. $\omega$-Aga-IIIA is a 76 amino acid peptide with six net positive charges (Venema et al., 1992). If $\omega$-Aga-IIIA binds at or near the external mouth of the channel, its positive charges at the outside mouth of the channel may alter the local potential felt by the channel voltage sensors. This is consistent with the $\sim 7 \mathrm{mV}$ positive shift of the activation curve and the voltage dependence of tail current inhibition. In addition to altering channel gating, the toxin may decrease local Ba concentration and increase the energy barrier for Ba entry in the channel, due to electrostatic repulsion between $\mathrm{Ba}$ ions and the toxin's positive charges. Such effects could result in reduced inward channel current carried by Ba with smaller effects on outward current carried by Cs. This hypothesis is consistent with the observation that $\omega$-Aga-IIIA reduced the inward limb of the instantaneous current-voltage curve with much smaller effects on the outward limb. The relative insensitivity of outward currents to $\omega$-Aga-IIIA cannot be explained by voltage-dependent unbinding of the toxin; the toxin must stay bound to some channels that are not blocked at large test depolarizations, since tail currents are blocked instantly upon repolarization from big test potentials. The results from noise analysis are compatible with a reduction of channel permeation to $\mathrm{Ba}$ ions, but they do not rule out the possibility that $\omega$-Aga-IIIA only affects channel gating for example by stabilizing a channel sub-state with low conductance.

The data do not exclude the possibility that P-type Ca channels may be heterogeneous, with one population sensitive to both $\omega$-Aga-IIIA and $\omega$-Aga-IVA and the other sensitive only to $\omega$-Aga-IVA. In such case, $\omega$-Aga-IIIA-sensitive channels might be twice as large as $\omega$-Aga-IIIA-insensitive channels, which would be consistent with the report of different subconductances for P-type channels in Purkinje neurons (Usowicz et al., 1992).

Evidence favoring a single population of $\omega$-Aga-IIIA-sensitive P-type channels is only indirect. The fraction of P-type current blocked by $\omega$-Aga-IIIA was rather constant in different Purkinje neurons (if assessed at the same test pulse potential), which seems unlikely if two distinct types of channels are involved. The strongest argument against distinct populations comes from the voltage dependence of block, especially from the near lack of block at test potentials positive to $+20 \mathrm{mV}$. It is difficult to imagine why a population of $\omega$-Aga-IIIA-sensitive Ca channels would not contribute current positive to $+20 \mathrm{mV}$. A definite answer will require studies of $\omega$-Aga-IIIA block of P-type channel at the single-channel level.

\section{Comparison with block of $N$-type and L-type channels}

$\omega$-Aga-IIIA block of P-type current was potent, with an estimate for the $K_{d}$ of $\sim 0.5 \mathrm{nM}$, derived from the toxin on rate and off rate time constants. Such potency would be similar to that of $\omega$-Aga-IIIA block of N-type currents in frog sympathetic neurons and L-type Ca currents in rat sensory ncurons and cardiac cells (Mintz et al., 1991), suggesting that P-, L-, and N-type Ca channels may all possess a similar $\omega$-Aga-IIIA binding site. $\omega$-AgaIIIA block of P-, L-, and N-type currents is not identical, however. In cardiac cells, $\omega$-Aga-IIIA completely suppresses L-type $\mathrm{Ca}$ inward and outward currents at all potentials, without affecting gating currents (Cohen et al., 1992; I. M. Mintz and B. P. Bean, unpublished observations). In frog sympathetic neurons, block of N-type current is partial, slightly voltage dependent, and accompanied by a reduction in the single-channel current estimated by noise analysis (L. M. Boland, Mintz, and Bean, unpublished observations). In Purkinje neurons, block of P-type current is even less complete, more voltage dependent, and may be accompanied by a reduction in the single channel current and a change in channel gating. It will be interesting to see whether the same blocking mechanism is involved in L-, $\mathrm{N}$-, and P-type channel block by $\omega$-Aga-IIIA, with small alterations of the binding site specific to each channel type.

The results suggest that the spider toxin $\omega$-Aga-IIIA is not a very good tool for functional distinctions between different highthreshold Ca channels in neurons. The toxin lacks selectivity in distinguishing between high-threshold $\mathrm{Ca}$ channels. It does discriminate between high- and low-threshold Ca current in neurons, but the incomplete block of the high-threshold currents prevents its use to isolate T-type current. The toxin is most interesting as a potent and complete blocker of L-type channels in cardiac cells (Mintz et al., 1991) and as a high-affinity ligand for neuronal high-threshold $\mathrm{Ca}$ channels. If it does recognize a similar binding site on the outer face of neuronal high-threshold $\mathrm{Ca}$ channels, it may be a valuable tool for studies of regions common to these channels.

\section{References}

Anwyl R (1991) Modulation of vertebrate neuronal $\mathrm{Ca}^{2+}$ channels by transmitters. Brain Res Rev 16:265-281.

Bcan BP (1985) Two kinds of calcium channcls in canine atrial cells. J Gen Physiol 86:1-30.

Bean BP (1989) Classes of calcium channels in vertebrate cells. Annu Rev Physiol 51:367-384.

Boland LM, Mintz IM, Adams ME, Bean BP (1992) Inhibition of N-type calcium channels in bullfrog sympathetic neurons by transmitters and toxins. Biophys $\mathrm{J}$ 61:1435.

Carbone E, Lux HD (1984) A low voltage-activated fully inactivating Ca channel in vertebrate sensory neurons. Nature 310:510-502.

Cohen CJ, Ertel EA, Smith MM, Venema VJ, Adams ME, Leibowitz MD (1992) High affinity block of myocardial L-type calcium channels by the spider toxin $\omega$-Aga-IIIA: advantages over 1,4-dihydropyridines. Mol Pharmacol 42:947-951.

Ellinor PT, Zhang J-F, Randall AD, Zhou M, Schwartz TL, Tsien RW, Hornc WA (1993) Functional cxpression of a rapidly inactivating neuronal calcium channel. Nature 363:455-458.

Fisher RE, Gray R, Johnston D (1990) Properties and distribution of single voltage-gated calcium channels in adult hippocampal neurons. J Neurophysiol 64:91-104. 
Fox AP, Nowycky MC, Tsien RW (1987a) Kinetic and pharmacological properties distinguishing three types of calcium currents in chick sensory neurons. J Physiol (Lond) 394:149-172.

Fox AP, Nowycky MC, Tsien RW (1987b) Single channel recordings of three types of calcium channels in chick sensory neurons. J Physiol (Lond) 394:173-200.

Fujita Y, Mynlieff M, Dirksen RT, Kim M-S, Niidome T, Nakai J, Friedrich T, Iwabe N, Miyata T, Furuichi T, Furutama D, Mikoshiba K, Mori Y, Beam KG (1993) Primary structure and functional expression of the $\omega$-conotoxin-sensitive $\mathrm{N}$-type calcium channel from rabbit brain. Neuron 10:585-598.

Furshpan EJ, Potter DD (1989) Seizure-like activity and cellular damage in rat hippocampal neurons in cell culture. Neuron 3:199-207.

Hamill OP, Marty A, Neher E, Sakmann B, Sigworth FJ (1981) Improved patch-clamp techniques for high-resolution current recordings from cells and cell-free membrane patches. Pfluegers Arch 391:85100.

Hess P (1990) Calcium channels in vertebrate cells. Annu Rev Neurosci 13:337-356.

Hess P, Lansman JB, Tsien RW (1984) Different modes of gating behavior favored by dihydropyridine $\mathrm{Ca}$ agonists and antagonists. Nature 311:538-544.

Hui A, Ellinor PT, Krizanova O, Wang J-J, Diebold RJ, Schwartz A (1991) Molecular cloning of multiple sublypes of a novel rat brain isoform of the $\alpha 1$ subunit of the voltage-dependent calcium channel. Neuron 7:35-44.

Kerr LM, Yoshikami D (1984) A venom peptide with a novel presynaptic blocking action. Nature 308:282-284.

Kiskin NI, Krishtal OA, Tsyndrenko AY (1990) Cross-desensitization reveals pharmacological specificity of excitatory amino-acid receptors in isolated hippocampal neurons. Eur J Neurosci 2:461-470.

Komuro H, Rakic P (1992) Selective role of N-type calcium channels in neuronal migration. Science 257:806-809.

Llinas R, Sugimori M, Lin JW, Cherskey B (1989) Blocking and isolation of a calcium channel from neurons in mammals and cephalopods utilizing a toxin fraction (FTX) from funnel-web spider poison. Proc Natl Acad Sci USA 86:1689-1693.

Llinas R, Sugimori M, Hillman DE, Cherskey B (1992) Distribution and functional significance of the P-type, voltage-dependent $\mathrm{Ca}^{2+}$ channels in the mammalian central nervous system. Trends Neurosci 15:351-355.

McEnery MW, Snowman AM, Sharp AH, Adams ME, Snyder SH (1991) Purified $\omega$-conotoxin GVIA receptor of rat brain resembles a dihydropyridine-sensitive L-type calcium channel. Proc Natl Acad Sci USA 88:11095-11099.

Miller RJ (1992) Voltage-sensitive $\mathrm{Ca}^{2+}$ channels. J Biol Chem 267: 1403-1406.

Mintz IM, Bean BP (1993) GABA B $_{B}$ receptor inhibition of P-type calcium channcls in central neurons. Neuron 10:889-898.

Mintz IM, Venema VJ, Adams ME, Bean BP (1991) Inhibition of Nand L-type $\mathrm{Ca}^{2+}$ channels by the spider venom toxin $\omega$-Aga-IIIA. Proc Natl Acad Sci USA 88:6628-6631.

Mintz IM, Venema VJ, Swiderek K, Lee T, Bean BP, Adams ME (1992a)Ptype calcium channels blocked by the spider toxin $\omega$-Aga-IVA. Nature 355:827-829.

Mintz IM, Adams ME, Bean BP (1992b) P-Type calcium channels in rat central and peripheral neurons. Neuron 9:85-95.

Mogul DJ, Fox AP (1991) Evidence for multiple types of $\mathrm{Ca}^{2+}$ channels in isolated hippocampal CA3 neurones of the guinea-pig. J Physiol (Lond) 433:259-281.

Mogul DJ, Adams ME, Fox AP (1993) Differential activation of adenosine receptors decreases $\mathrm{N}$-type but potentiates $\mathrm{P}$-type $\mathrm{Ca}^{2+}$ channels in hippocampal CA3 ncurons. Neuron 10:327-334.

Mori Y, Friedrich T, Kim M-S, Mikami A, Nakai J, Ruth P, Bosse E, Hofmann F, Flockerzi V, Furuichi T, Mikoshiba K, Imoto K, Tanabe
T, Numa S (1991) Primary structure and functional expression from a complementary DNA of a brain calcium channel. Nature 350:398402.

Nowycky MC, Fox AP, Tsien RW (1985a) Three types of neuronal calcium channel with different calcium agonist sensitivity. Nature 316:440-443.

Nowycky MC, Fox AP, Tsien RW (1985b) Long-opening mode of gating of neuronal calcium channels and its promotion by the dihydropyridine agonist Bay K 8644. Proc Natl Acad Sci USA 82:21782182.

O'Dell TJ, Alger BE (1991) Single calcium channels in rat and guineapig hippocampal neurons. J Physiol (Lond) 436:739-767.

Olivera BM, Gray WR, Zeikus R, McIntosh JM, Varga J, Kivier J, de Santos V, Cruz LJ (1985) Peptide neurotoxins from fish-hunting cone snails. Science 230:1338-1343.

Pfrieger FW, Veselovsky NS, Gottmann K, Lux HD (1992) Pharmacological characterization of calcium currents and synaptic transmission between thalamic neurons in vitro. J Neurosci 12:4347-4357.

Plummer MR, Logothetis DE, Hess P (1989) Elementary properties and pharmacological sensitivities of calcium channels in mammalian peripheral neurons. Neuron 2:1453-1463.

Rampe D, Triggle DJ (1989) 1,4-Dihydropyridine activators and antagonists: structural and functional distinctions. Trends Pharmacol Sci 10:507-511.

Regan LJ (1991) Voltage-dependent calcium currents in Purkinje cells from rat cerebellar vermis. J Neurosci 11:2259-2269.

Regan LJ, Sah DWY, Bean BP (1991) $\mathrm{Ca}^{2+}$ channels in rat central and peripheral neurons: high-threshold current resistant to dihydropyridine blockers and $\omega$-conotoxin. Neuron 6:269-280.

Snutch TP, Reiner PB (1992) $\mathrm{Ca}^{2}+$ channels: diversity of form and function. Curr Opin Neurobiol 2:247-253.

Snutch TP, Tomlinson WJ, Leonard JP, Gilbert MM (1991) Distinct calcium channels are generated by alternative splicing and are differentially expressed in the mammalian CNS. Neuron 7:45-57.

Soong TW, Stea $A$, Hodson CD, Dubel SJ, Vincent SR, Snutch TP (1993) Structure and functional expression of a member of the low voltage-activated calcium channel family. Science 260:1133-1136.

Swandulla D, Carbone E, Lux HD (1991) Do calcium channel classification account for neuronal calcium channel diversity? Trends Neurosci 14:46-51

Tsien RW, Lipscombe D, Madison DV, Bley KR, Fox AP (1988) Multiple types of neuronal calcium channels and their selective modulation. Trends Neurosci 11:431-438.

Tsien RW, Ellinor PT, Horne WA (1991) Molecular diversity of voltage-dependent $\mathrm{Ca}^{2+}$ channels. Trends Pharmacol Sci 12:349-354.

Turner TJ, Adams MF, Dunlap K (1992) Calcium channels coupled to glutamate release identified by $\omega$-Aga-IVA. Science 258:310-313.

Usowicz MM, Sugimori M, Cherskey B, R Llinas (1992) P-type $\mathrm{Ca}^{2+}$ channels in the somata and dendrites of adult cerebellar Purkinje cells. Neuron 9:1185-1199.

Venema VJ, Swiderek KM, Lee TD, Hataway GM, Adams ME (1992) Antagonism of synaptosomal calcium channels by subtypes of $\omega$-agatoxins. J Biol Chem 267:2610-2615.

Williams ME, Feldman DH, McCue AF, Brenner R, Velicelebi G, Ellis $\mathrm{SB}$, Harpold MM (1992a) Structure and functional expression of $\alpha 1, \alpha 2$, and $\beta$ subunits of a novel human neuronal calcium channel subtype. Neuron 8:71-84.

Williams ME, Brust PF, Feldman DH, Patthi S, Simerson S, Maroufi A, McCue AF, Velicelebi G, Ellis S, Harpold MM (1992b) Structure and functional expression of an $\omega$-conotoxin-sensitive human $\mathrm{N}$-type calcium channel. Science 257:389-395.

Witcher DR, De Waard M, Sakamoto J, Franzini-Amstrong C, Pragnell M, Kahl SD, Campbell KP (1993) Subunit identification and rcconstitution of the $\mathrm{N}$-type $\mathrm{Ca}^{2+}$ channel complex purified from brain. Science 261:486-489. 